INTERNATIONAL JOURNAL OF RESEARCHES IN BIOSCIENCES, AGRICULTURE \& TECHNOLOGY ( ) VISHWASHANTI MULTIPURPOSE SOCIETY (Global Peace Multipurpose Society) R. No. MH-659/13(N) www.vmsindia.org

\title{
MICROBIOLOGICAL ASSESSMENT AND STUDY OF PHYSICO-CHEMICAL PARAMETERS OF NIRA RIVER IN DRY \& WET SEASON
}

\author{
1Mane S.H., ${ }^{2}$ Kamble B.S. and ${ }^{3}$ Girhe B.E. \\ ${ }^{1}$ G.K.G. College, Kolhapur (M.S) India \\ 2J.J.T.U. Rajasthan, India \\ ${ }^{3}$ Mudhoji College, Phaltan, Satara (M.S) India \\ Email: sudam_mane@rediffmail.com
}

\begin{abstract}
Microbiological assessment and physic-chemical parameters of Nira River were carried out during dry and wet season to determine whether the discharges are within tolerable limits. All the physico-chemical parameters studied showed seasonal variations. Higher temperature and lower $\mathrm{p}^{\mathrm{H}}$ values were values were recorded during the dry season than wet season. Similarly, the BOD of fresh water, the lotic water decreases from $10000 \mathrm{mg} / \mathrm{ml}$ during the dry season to $6000 \mathrm{mg} / \mathrm{ml}$ in the wet season. Conversely, the BOD of the final waste discharge was $4000 \mathrm{mg} / \mathrm{ml}$ during dry season and 3.500 $\mathrm{mg} / \mathrm{ml}$ during the wet season. The COD showed similar trend, with values ranges from 12.200 to 18.500 $\mathrm{mg} / \mathrm{ml}$ depending on the season. The suspended solid values ranged from 1200 to $1950 \mathrm{mg} / \mathrm{ml}$. The phosphate and nitrate ions were in the range of $41-75 \mathrm{mg} / \mathrm{ml}$. and $22.5-960 \mathrm{mg} / \mathrm{ml}$ respectively. The following bacteria species were also encountered:

B. cereus, E. coli, Micrococcus sp, S.typhi. The results showed significantly high level of pollutants in the waste discharged in Nira River.
\end{abstract}

Keywords: Physico-chemical; Microbiological; Nira River; Pollution.

\section{Introduction:}

Nira River, its water used for various purposes is an establishment where Discharge from various smart villages slaughter regions, Municipal waste, domestic waste, and industrial waste fall among the groups in river, its waste water consists mainly of water and suspended solids (sand particles and industrial wastes meat bone bits), soluble organic and inorganic ions ( Ten Hare, 1976 ). It also contains high amount of nutrients therefore aiding the growth of micro organisms such as bacteria, viruses, protozoa and intestinal parasites which have been know to cause enteric infections in man (Okafar for, 1985). All waste primary treatment involves screening, sedimentation, chemical precipitation, tricking filters and activated sludge processes (Targanides et.al. 1979). Screening removes coarse materials such as bone bites, Dung, hair, flesh, paunch and floating solid by rotator wire mesh. Sedimentation removes $63 \%$ of suspended solid, of BOD, tricking filters removes between 81 and $90 \%$ BOD with on accompany nuisance (Black and Brown, 1974). Blood is separated and all suspended solid are reduced by addition of alum. Fat is extracted by introducing a preheating salient, which untie with the fat in the material to form a concentration micelle, removed by settling tanks and passed to an evaporator.

Aerobic bacteria breakdown the organic material, when there is sufficient supply of oxygen available. Ammonia is converted to nitrite, mineralization increases due to volatile solids and aerobic treatment removes biodegradable organic matters from waste water (Burchbaker et.al 1971). All these procedure are not practiced at smart village. Indeed most operations are carried out by illiterate butchers under largely unhygienic conditions and the standard procedures.

This study was embarked upon to assess he microbiological and physicochemical qualities of the waste water discharges at Nira River with a view to determining the level of pollution being discharged into the environment and to make recommendations.

Materials and Methods:

Study area of Nira River from it origin up to Ghokhali (around Pune and Satara District), the Bhore, Nira and Gohkali is on high land area of vegetation of medium grassland adjacent to the Satara and Pune. The Satara and Pune is a standard one containing big and larges, cattle pens, refuse houses, drainage ditch, bore holes, 
municipal water taps meat inspection laboratory a slaughtering places and rigions. Slaughtering procedure:

Which has been replaced by slaughtering Pilgrims, Goats, Sheeps and other cattles are rested at the large before slaughtering process commenced. All waste including blood, paunch, hide, dung, hairs fat and dirt are virtually washed down as waste water, which undergo minor treatment before being discharge.

\section{Sampling:}

Samples were collected at ten stations within the months of November and December 2007 (representing dry season) and May and June 2008 wet season.

\section{Sample a (i to v) stations:}

$100 \mathrm{ml}$ of runoff from the waste water was ascetically connected into the a presterilize $500 \mathrm{ml}$ amber jars.

\section{Sample b (vi to $x$ ) stations:}

$100 \mathrm{ml}$ of waste water from the lauage discharging into the municipal sewer was collected in presterilize $500 \mathrm{ml}$.

The samples were then taken straight to laboratory for microbiological and physicochemical analysis.

\section{Phycicochemical analysis:}

The following Physicochemical parameters were determined using standard methods (APHA, 1972)

Temperature,

concentration $\left(\mathrm{p}^{\mathrm{H}}\right)$, suspended solids, chemical oxygen demand (COD), Biochemical oxygen demand (BOD). The concentrations of the following ions were also determined by phosphate, nitrate, nitrite sulphate, sulphide, and chlorine. Finally, the concentration of the following heavy metals was determined Iron, Copper and Chromium.

\section{Microbiological analysis:}

Samples were plated on the following media within two hours of collection. Plate count Agar (for total bacterial count) McCone agar (for E. coli, salmonella sp and shigella) S-SAgar (for Salmonella - Shigella L-Eosine Methylene Blue agar (for E. coli) and PDA (for fungal and yeast).

Serial dilution of each sample was carries out in test tubes using sterile distilled water. $1 \mathrm{ml}$ of $10^{6}$ dilution was plated (using the pour plates method) into the appropriate media. The plates were incubated at $37^{\circ} \mathrm{c}$ for 24 hours for bacterial isolates and 72 hours for fungal isolates. Thereafter colonies appearing on plates were counted and purified by sub culturing on fresh agar plates. The organisms were later identified using standard methods Cowan and Steel, 1974).

\section{Results and discussion:}

The result of the physicochemical analysis is shown in table 1 . Higher values were recorded in $\mathrm{I}$ to $\mathrm{V}$ (A) in the following parameters during the dry season $\mathrm{p}^{\mathrm{H}}$, conductivity, dissolved solids and Nitrate ion while Sample B VI to X recorded higher values in the following parameters color, Temperature Suspended solid Turbidity, Phosphate, Sulphate, Sulphite, chlorine, BOD, COD, Iron and copper.

Similarly during the wet season, sample $\mathrm{I}$ to $\mathrm{V}$ (A) recorded higher values in suspended solids, turbidity, and most other parameters except phosphate iron concentration and $\mathrm{p}^{\mathrm{H}}$. Comparative analysis of the two seasons was recorded. The following parameters colour, Temperature, Suspended solid Turbidity, Dissolved solid, Nitrate, Phosphate, Sulphate, BOD, COD, Iron, Copper and Chloride irons were recorded for dry seasons. The wet season recorded higher values in $\mathrm{p}^{\mathrm{H}}$, sulphite. The result of the microbiological analysis is shown in Table 2. The following bacterial species were indentified. There was not much difference in the bacteria load of the waste from Sample (A) I to V and the waste discharging out (effluent) (Sample B) VI to X. However higher fungal count was recorded in the dry season than wet season.

Table-1. Physicochemical analysis of effluent from origine of Nira River around Pune and Satara District during dry and wet season.

(Each figure is an average of 3 readings) of each stations.

\begin{tabular}{|l|c|c|c|c|}
\hline $\begin{array}{l}\text { Average } \\
\text { values }\end{array}$ & \multicolumn{2}{|c|}{$\begin{array}{l}\text { Wet season } \\
\text { Month and Time }\end{array}$} & \multicolumn{2}{c|}{$\begin{array}{c}\text { Dry Season } \\
\text { Month and Time }\end{array}$} \\
\hline & $\begin{array}{c}\text { Oct. } \\
2007\end{array}$ & $\begin{array}{c}\text { Dec. } \\
2007\end{array}$ & $\begin{array}{c}\text { May } \\
2008\end{array}$ & $\begin{array}{c}\text { June } \\
2008\end{array}$ \\
\hline \multirow{4}{*}{ Sample } & Sample & Sample & Sample & Sample \\
& $\begin{array}{c}\text { A } \\
\text { I to V } \\
\text { station }\end{array}$ & $\begin{array}{c}\text { B } \\
\text { VI to X } \\
\text { station }\end{array}$ & $\begin{array}{c}\text { A to V } \\
\text { II to X }\end{array}$ \\
\hline
\end{tabular}




\begin{tabular}{|l|c|c|c|c|}
\hline Color & 9.850 & 3800 & 5.206 & 3.100 \\
\hline $\mathrm{pH}$ & 6.70 & 6.82 & 7.17 & 7.21 \\
\hline Temp ${ }^{\circ} \mathrm{c}$ & 35.5 & 34.5 & 28 & 26 \\
\hline $\begin{array}{l}\text { Suspended } \\
\text { solid(md/1) }\end{array}$ & 1950 & 1900 & 1600 & 1200 \\
\hline $\begin{array}{l}\text { Conductivity } \\
\text { (ms/cm) }\end{array}$ & 4.08 & 14.83 & 10 & 9 \\
\hline $\begin{array}{l}\text { Turbidity } \\
\text { (FTU) }\end{array}$ & 7075 & 4750 & 5.200 & 3.750 \\
\hline $\begin{array}{l}\text { Dissolved } \\
\text { solid (mg/l) }\end{array}$ & 2040 & 7410 & 1.500 & 1.800 \\
\hline $\begin{array}{l}\text { Nitrate } \\
\text { (mg/l) }\end{array}$ & 600 & 960 & 33 & 22.5 \\
\hline $\begin{array}{l}\text { Phosphate } \\
\text { (mg/l) }\end{array}$ & 75.9 & 49.75 & 24 & 41 \\
\hline $\begin{array}{l}\text { Sulphate } \\
\text { (mg/l) }\end{array}$ & 1900 & 1300 & 420 & 250 \\
\hline $\begin{array}{l}\text { Sulphite } \\
\text { (mg/l) }\end{array}$ & 5.780 & 4.58 & 13.8 & 9.50 \\
\hline $\begin{array}{l}\text { Chlorine } \\
\text { (mg/l) }\end{array}$ & 740 & 280 & 179 & 98 \\
\hline BOD(mg/l) & 10000 & 4000 & 6.000 & 3.500 \\
\hline COD (mg/l) & 18.500 & 15.000 & 14.200 & 12.200 \\
\hline Iron (mg/l) & 144 & 40 & 78 & 55 \\
\hline Chromium & 144 & 12.4 & 120 & 104 \\
\hline Copper & 76.3 & 56.3 & 57 & 15 \\
\hline
\end{tabular}

The sample A (I to V) and effluents were observed to have the characteristics greenish brown colour, which was obviously due to presence of Pilgrim; Domestic, and Municipal waste. Expectedly high figures were recorded in the parameters screened with the waste meat domestic and municipal waste higher than the effluent because the later had undergone some mild treatment. The high BOD values recorded is an indication of high microbial activities resulting in high demand for available dissolved oxygen. Similar reasons could be adduced for the high value of the COD is typical characteristics of Nira River wasted and it indicates a very high risk if such wastes are not properly treated before discharge (Griffiths, 1981). Where results obtained for the two seasons will be seen that generally decrease for discharged organic items as well as the $\mathrm{p}^{\mathrm{H}}$ in wet

seasons. This can be attributed to flooding or availability of more water therefore more of these ions get dissolved (Odiete - 1999). The high sulphate contain observed are potentially hazardous because it can lead to increase in sulphate contain manure of from live stock as well as in the environment (Dunham et.al., 1985). The phosphate, nitrate and other ions are potential source in receiving wasters. The heavy metals detected might be from the water feeds of the live stock. The of effect of heavy metal in the environment is well known (Ndiok were and Guinn, 1979). The microbial assessment showed the presences of or conform group as well as other hazdous microbes. The exterior of cattle's (cow, goat, sheep, and buffallow) harbors large numbers of many kinds of micro organisms from the winter feed and manure as well as its natural. Flora and intestinal content (Frazier and Westhoff, 1988). No seasonal variation was noticed in the waste. However, the fungi counts were higher in the dry season obviously due to the presence of many salt containing spores in the environment. Overall, it was seen that the Nira River do not conform to the FEPA (Federal Environmental Protection Agency) standard (FEPA 1991). Almost all parameters screened exceeded the recommended limits by very wide margins. Thus, these discharges are quite harmful to the receiving body of water and subsequently to the exposed communities.

Table-2. Distribution of the various groups if aerobic microorganisms in effluents discharge from Nira River (Each figure represents an average of 3 readings)

\begin{tabular}{|c|c|c|c|c|}
\hline $\begin{array}{l}\text { Sample } \\
\text { source }\end{array}$ & $\begin{array}{c}\text { Mean total } \\
\text { heterotrophs } \\
\text { Bacteria } \\
\text { (cfu/ml) }\end{array}$ & $\begin{array}{c}\text { Mean total } \\
\text { Coliform and } \\
\text { pathogenic } \\
\text { bacteria(cfu/ } \\
\text { ml) }\end{array}$ & $\begin{array}{l}\text { Mean } \\
\text { total } \\
\text { Fungi } \\
\text { (cfu/ml) }\end{array}$ & months \\
\hline $\begin{array}{l}\text { Sample } \\
\text { A I to V }\end{array}$ & $2.0^{\times} 10^{8}$ & $5.0^{\times} 10^{7}$ & $5.0^{\times} 10^{3}$ & \multirow{2}{*}{$\begin{array}{l}\text { Oct. to } \\
\text { Dec. } \\
2007\end{array}$} \\
\hline $\begin{array}{l}\text { Sample } \\
\text { B VI to } \\
\text { X }\end{array}$ & $2.2^{\times} 10^{8}$ & $2.0^{\times} 10^{7}$ & $6.0^{\times} 10^{7}$ & \\
\hline $\begin{array}{l}\text { Sample } \\
\text { A I to V }\end{array}$ & $1.5^{\times} 10^{8}$ & $2.2^{\times} 10^{7}$ & $3.0 \times 10^{7}$ & \multirow{2}{*}{$\begin{array}{c}\text { May to } \\
\text { June } \\
2008\end{array}$} \\
\hline $\begin{array}{l}\text { Sample } \\
\text { B VI to } \\
\text { X }\end{array}$ & $12^{\times} 10^{8}$ & $16^{\times} 10^{7}$ & $30 \times 10^{7}$ & \\
\hline
\end{tabular}




\section{Conclusion:}

Higher values of $\mathrm{p}^{\mathrm{H}}$, conductivity, dissolved solids and Nitrate ion color, Temperature Suspended solid Turbidity, Phosphate, Sulphate, Sulphite, chlorine, BOD, COD, Iron and copper were recorded in dry season while in wet season, higher values recorded in suspended solids, turbidity, and most other parameters except phosphate iron concentration and $\mathrm{p}^{\mathrm{H}}$. In microbiological analysis higher fungal count was recorded in the dry season than wet season. Overall it was seen that the Nira River do not conform to the FEPA (Federal Environmental Protection Agency) standard (FEPA 1991). Almost all parameters screened exceeded the recommended limits by very wide margins. Thus, these discharges are quite harmful to the receiving body of water and subsequently to the exposed communities.

\section{Acknolwedgements:}

Our gratitude is due to the management of the U.G.C. (W.R.O.) Pune, research laboratory, and library of NCL, IIT Bombay, Shivaji University, Kolhapur, G.K.G. College, Kolhapur and Mudhoji College, Phaltan, Satara, M.S.

\section{References:}

Adegole G.O.,(1981): Characterization of staphylococci isolated form goats, I. Coagulase activities and antibiotic sensitivity patterns. Zbe. Bokt. Hyg. I Abt. Orig. A., 244, 431-437.

Apha, (1972): Standard methods for the examination of water and waste water, 15 th ed. APHA-AWWA-WPCF. Washinton D.C.

Black, MG and S.M. Brown, (1974): Operational experience with all abattoir waste digestion plant.Wat. Poll. Con, 208, 532-537.

Burchbaker A.F., J.E. Garton, W.A. Maholley and M.D Pame,(1971): Evaluation of Beef cattle feed or waste management alternatives. Environment protection agency. Oklahoma agricultural experimental station, Oklahoma state university, still water Oklahoma.

Cowan S.T.,(1974): Cowan and Steel's manual for identification od medical bacteria (2nd ed). Cambridge University Press, Cambridge.

Durham K.S., J.Yeggy and P.R. Dague, (1985): Chemicophysical parameters of liquid manure from some confinement facilities, Health implications for warders, swine and the environment agricultural waste, 14, 97-113.

Federal Environmental Protection Agency, (1991): National guidelines and standard pollution in Nigeria I: Federal republic of Nigeria official gazette Federal Government press, Lagos, 78 (42).

Fraizer W.C., Westhff, (1988): Food microbiology, Tata McGraw-Hill publishing company ltd., New Delhi.

Griffiths A, (1981): Animal by - product process and effluents. In food industry waste: Disposal and recovery, (Eds: A Herzka and R.G. Booth). Applied science publishers, London and New Jersey. Pp. 171-183.

Ndiokwere C.L. and V.P. Guinn,(1983): Determination of some toxic trace metals in Nigeria river and harbor water samples neutron activation analysis, J. Radioanal, Chem. 79, 147-151.

Odiete W.O, (1999): Environmental physiology of animals and pollution Diversified Resources Ltd.

Okafor N,(1985): Aquatic and waste microbiology, 1st Edition Fourth dimension publishing company ltd., Nigeria.

Scarafoni G.S., (1995): Hygiene construction and technical organization of slaughter houses, In: Meat hygiene 7 (Ed: Albertson et al.), World Health Organization Genera.

Targanides E.R., K.C., Chou and B.Y. lee: Animal waste management and utilization in Singapore. Agric. Waste, 1, 129-141 (1997). 